\title{
Surgical management for unruptured sinus of Valsalva aneurysms: a narrative review of the literature
}

\author{
Quynh Nguyen ${ }^{1}$, Dominique Vervoort ${ }^{2}$, Kevin Phan $^{3}$, Jessica G. Y. Luc ${ }^{4}$ \\ ${ }^{1}$ Faculty of Medicine and Dentistry, University of Alberta, Edmonton, AB, Canada; ${ }^{2}$ John Hopkins Bloomberg School of Public Health, Baltimore, \\ MD, USA; ${ }^{3}$ NeuroSpine Surgery Research Group, Prince of Wales Private Hospital, Sydney, Australia; ${ }^{4}$ Division of Cardiovascular Surgery, \\ Department of Surgery, University of British Columbia, Vancouver, BC, Canada \\ Contributions: (I) Conception and design: JGY Luc; (II) Administrative support: JGY Luc; (III) Provision of study materials or patients: None; (IV) \\ Collection and assembly of data: JGY Luc, Q Nguyen; (V) Data analysis and interpretation: JGY Luc, Q Nguyen; (VI) Manuscript writing: All \\ authors; (VII) Final approval of manuscript: All authors. \\ Correspondence to: Jessica G. Y. Luc, MD. Division of Cardiovascular Surgery, University of British Columbia, 1081 Burrard Street, Unit 486, \\ Vancouver, BC, V6Z 1Y6, Canada. Email: jessicagyluc@gmail.com.
}

\begin{abstract}
Unruptured sinus of Valsalva aneurysms (SVAs) are rare cardiac lesions that arise due to congenital or acquired etiologies. They could be asymptomatic or cause various clinical manifestations as a consequence of their mass effect on the coronary arteries, heart valves, and other adjacent structures. While the factors predicting SVA rupture are not fully understood, ruptured SVAs carry a high complication and mortality rate, highlighting the need for early recognition and management of unruptured SVAs. Imaging modalities such as echocardiography, computed tomography (CT), angiography, and magnetic resonance imaging (MRI) are essential in identifying and characterizing the aneurysm as well as associated cardiac anomalies. However, there are no specific guidelines for the diagnosis and management of SVAs. Herein, we performed a contemporary systematic review to examine the presentation, diagnostic tests and findings, as well as outcomes for surgical intervention of unruptured SVAs. We demonstrate that surgical repair remains the preferred method of treatment in order to prevent complications such as rupture or thrombus formation. Surgery should be prompted in patients with symptomatic, large, or rapidly expanding unruptured SVAs, as well as those unruptured SVAs that contain intraluminal thrombi, have a mass effect on surrounding structures, or are recurrent. Surgical outcomes are generally good with favourable prognosis and minimal recurrence.
\end{abstract}

Keywords: Unruptured sinus of Valsalva aneurysms; sinus of Valsalva aneurysms (SVAs); surgical management

Submitted Aug 18, 2020. Accepted for publication Jan 08, 2021.

doi: $10.21037 /$ jtd-20-2682

View this article at: http://dx.doi.org/10.21037/jtd-20-2682

\section{Introduction}

Sinus of Valsalva (SV) aneurysm (SVA) is an enlargement of the aortic root area between the aortic valve annulus and the sinotubular junction. While the factors predicting SVA rupture are not fully understood, ruptured SVAs carry a high complication and mortality rate, highlighting the need for early recognition and management of unruptured SVAs (1).

SVAs can be congenital or acquired, with the former being more prevalent (2). The true prevalence of SVAs is unknown; the estimated rate is approximately $0.09 \%$ of the general population and $0.1 \%$ to $3.5 \%$ of all congenital cardiac defects (2). Multiple SVAs are even rarer with very few cases reported in the literature (3-5). SVAs most often affect one of the SVs, and originate predominantly from the right SV (RSV) $(2,6-9)$. Patients with unruptured SVAs could be asymptomatic or present with non-specific symptoms such as dyspnea, chest pain, palpitation and syncope (5,10-19). Unruptured SVAs may cause valvular regurgitation, annular dilation or deformity, as well as compression of the coronary arteries, cardiac chambers 
and outflow tracts (20-26). A comprehensive state-of-theart imaging review of SVAs has been reported, including various imaging modalities such as echocardiography, computed tomography (CT), angiography, and magnetic resonance imaging (MRI) that can be used for the diagnosis of SVAs (24-31). SVAs may rupture into cardiac chambers or extracardiac locations, and the type of complications depends on the locations into which the rupture occurs (31). The incidence of ruptured SVAs is unknown with only a single centre review of 53 SVA cases that reported ruptured SVAs in $64 \%$ of the cases (1). While size is one criterion which may be associated with rupture, the factors predicting SVA rupture are not fully understood. Ruptured SVAs carry a high mortality rate, with a mean survival period of 3.9 years if left untreated (1).

There are no specific guidelines for the diagnosis and management of SVAs, with medical and surgical options reported (32-38). While ruptured SOVAs require urgent surgical intervention, the management of unruptured SVAs remains controversial. Unruptured SVAs that do not require surgical intervention are managed conservatively using serial follow-up surveillance imaging (31). These imaging studies provide temporal data on the size and growth of the SVA, the relationship of SVA with the surrounding structures, and potential complications. The assessment and conservative management of unruptured SVAs using multimodality cardiovascular imaging have been thoroughly discussed in a recent review and will not be reviewed in this paper (31). On the other hand, the decision to intervene on unruptured SVA is complex and multifactorial, depending on the aneurysmal sizes, the growth trends on surveillance imaging, as well as patient clinical characteristics (2). Our study focuses on the surgical management of unruptured SVAs, which is an area subject to greater controversy.

The present systematic review aims to describe the contemporary clinical presentation, diagnostic tests and findings, as well as outcomes for surgical intervention of unruptured SVAs in patients with no associated congenital heart defects, underlying connective tissue disorders or other concomitant cardiac conditions. We present the following article in accordance with the Narrative Review reporting checklist (available at http://dx.doi.org/10.21037/jtd-20-2682).

\section{Methods}

\section{Literature search strategy}

Studies examining surgical outcomes of unruptured SVAs in adult patients were identified through electronic searches performed in June 2020 using Ovid Medline, Embase, Cochrane Database of Systematic Reviews, and Scopus. To achieve the maximum sensitivity of the search strategy, we combined the terms: "aneurysm", "aneurysms", "sinus of Valsalva", "unruptured", as well as "sinus of Valsalva aneurysms" as either keywords or MeSH terms. The reference lists of all retrieved articles were reviewed and assessed for further identification of potentially relevant studies using the inclusion and exclusion criteria. After removal of duplicates, 175 articles were screened in abstract and full-text, with 52 articles included in the final analysis (Figure 1).

\section{Selection criteria}

Eligibility of studies for the present systematic review was determined prior to commencement of data collection. These included all studies that were contemporary as defined as published after the year 2000, with described surgical management for the unruptured SVA in adult patients with no previous cardiac surgery or concomitant cardiac pathologies and no familial connective tissue diseases. All publications were limited to those involving human subjects and in the English language.

Articles were excluded if they were review articles, case reports/series on pediatric patients or published before the year 2000. Articles with insufficient information on management, those with conservative management, as well as those that described patients with familial lesions, systemic conditions, previous cardiac surgery or concomitant cardiac problems were also excluded. Papers without accessible full-texts online were also not included in our study.

\section{Data extraction}

All data was extracted from article texts, tables, and figures and discrepancies were resolved by group discussion and consensus.

\section{Statistical analysis}

Descriptive statistics were used. Non-parametric continuous variables are expressed as medians with the interquartile range (IQR). Categorical data were expressed as counts and percentages. Statistical analyses were performed using GraphPad Prism version 8.4.3, GraphPad Software, La Jolla California USA. 


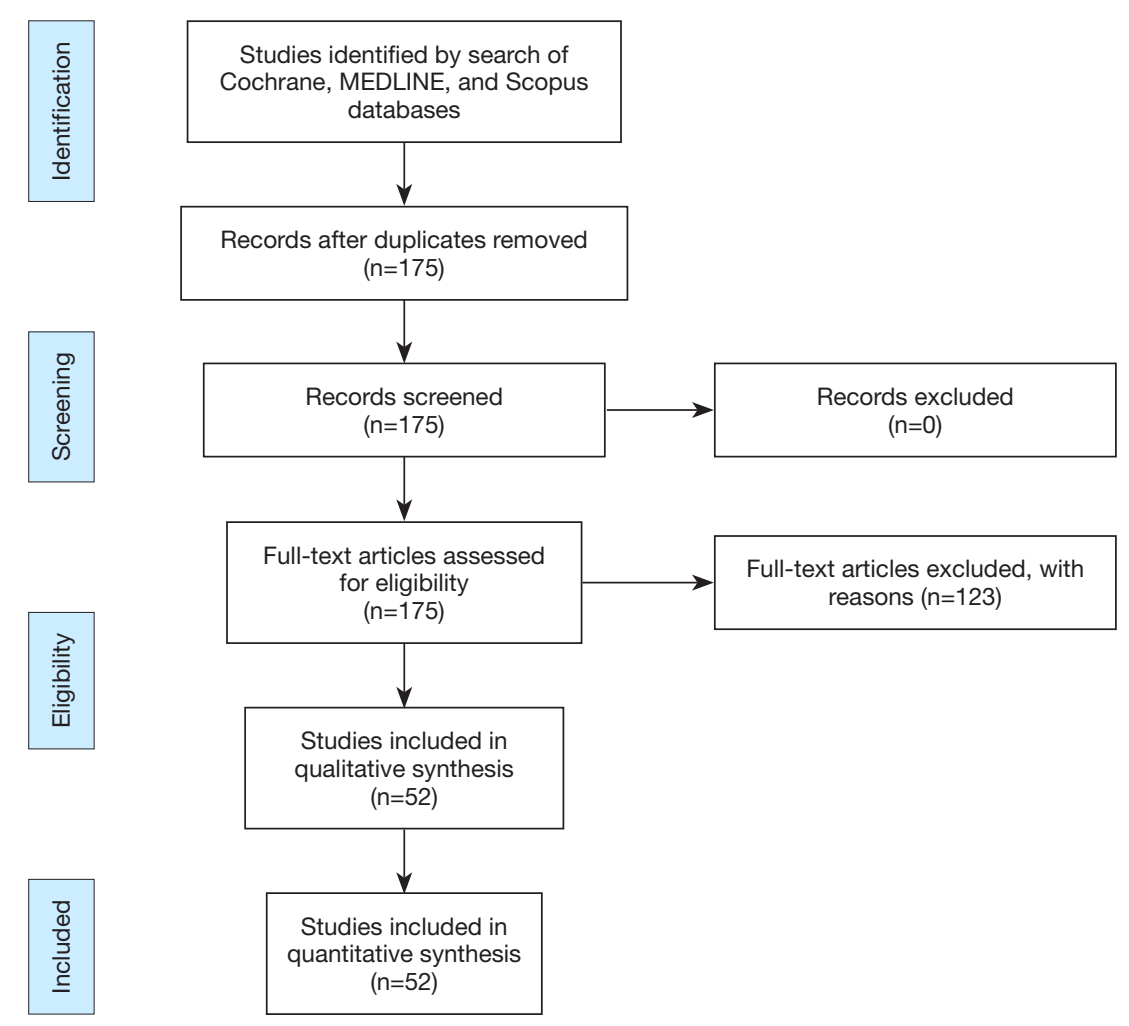

Figure 1 PRISMA schematic of the search strategy. PRISMA, Preferred reporting items for systematic reviews and meta-analyses.

\section{Results and discussion}

\section{Clinical presentation}

Unruptured SVAs can present at various ages, ranging from 21 to 84 years old (Table 1). The median age at presentation was 59 years old. Unruptured SVAs were more commonly reported in males $(58 \%, 30 / 52$ cases-patient's sex was unspecified in one case) than in females (42\%, 22/52 cases). Patients with SVAs can be asymptomatic ( $9 \%, 5 / 53$ cases) or present with non-specific symptoms such as dyspnea (43\%, $23 / 53$ cases), chest pain/pressure/tightness/discomfort (34\%, 18/53 cases), palpitations (15\%, $8 / 53$ cases), and syncope/presyncope ( $9 \%, 5 / 53$ cases). Other less common initial presentations reported include tonic clonic seizure ( $2 \%, 1 / 53$ cases), chronic cough ( $2 \%, 1 / 53$ cases), exertional intolerance $(2 \%, 1 / 53$ cases), fever ( $2 \%, 1 / 53$ cases), dizziness ( $2 \%, 1 / 53$ cases), orthopnea ( $2 \%, 1 / 53$ cases), and peripheral edema ( $2 \%, 1 / 53$ cases). More severe cases of unruptured SVAs can present with myocardial ischemia and infarction ( $9 \%, 5 / 53$ cases), heart failure ( $9 \%, 5 / 53$ cases), as well as cardiogenic shock ( $4 \%, 2 / 53$ cases). Among the patients who presented with signs and symptoms of heart failure, $4 \%$ were classified as New York Heart Association (NYHA) class II (2/53 cases), and $6 \%$ were classified as NYHA class III/IV (3/53 cases).

Murmur is a common finding (43\%, 23/53 cases) on physical examination of patients with unruptured SVAs. Among these described murmurs, a diastolic murmur was appreciated in $43 \%$ of the cases (10/23 cases). A systolic murmur was also appreciated in $43 \%$ of the cases $(10 / 23$ cases), with the majority of them being described as systolic ejection murmur (30\%, 7/23 cases). The majority of the reported murmurs were heard over the left sternal region $(48 \%, 11 / 23$ cases). Other areas such as aortic (13\%, $3 / 23$ cases), pulmonic ( $9 \%, 2 / 23$ cases), base ( $4 \%, 1 / 23$ cases), or mitral ( $4 \%, 1 / 23$ cases) have also been described. Most murmurs were grade 2 or 3 (26\%, 6/23 cases). Grades 1, 4, and 5 murmurs were each reported once among patients ( $4 \%, 1 / 23$ cases). Information on the characteristics of these murmurs was scarce: $9 \%(2 / 23$ cases) were described as blowing, $4 \%$ (1/23 cases) was described as soft and $4 \%(1 / 23$ cases) was described as regurgitant murmur. 
Table 1 Demographic and clinical presentation of previously described cases of sinus of Valsalva aneurysms

\begin{tabular}{|c|c|c|c|c|c|c|c|c|c|c|c|c|c|c|c|c|}
\hline \multirow{2}{*}{ Patient No } & \multirow{2}{*}{ Reference } & \multirow{2}{*}{ Year } & \multirow{2}{*}{ Age } & \multirow{2}{*}{ Sex } & \multicolumn{8}{|c|}{ Clinical presentation } & \multirow{2}{*}{ Others } & \multirow{2}{*}{ NYHA Class } & \multirow{2}{*}{ Murmur (timing/grade/quality/location) } & \multirow{2}{*}{ Comorbidities } \\
\hline & & & & & Asymptomatic & Dyspnea & Chest pain & Palpitation & Syncope & Arrhythmia & Conduction defect & $\mathrm{MI}$ & & & & \\
\hline 1 & Pólos et al. (8) & 2020 & 68 & M & - & $\mathrm{Y}$ & - & - & - & - & - & - & - & IIII-IV & - & Smoker \\
\hline 2 & Serban et al. (9) & 2019 & 49 & M & - & - & Y & - & - & - & - & - & - & - & - & - \\
\hline 3 & Wang et al. (10) & 2019 & 46 & M & - & Y & - & - & - & - & - & - & - & - & Systolic/-//mitral; Diastolic///// aortic & - \\
\hline 4 & Umeda et al. (11) & 2018 & 69 & $\mathrm{~F}$ & - & $\mathrm{Y}$ & - & - & - & - & - & - & - & - & - & - \\
\hline 5 & Khanna et al. (13) & 2017 & 55 & M & - & - & Y & - & - & - & - & - & - & - & - & - \\
\hline 6 & Ponti et al. (14) & 2017 & 71 & M & - & Y & Y & - & - & - & - & - & Myocardial ischemia & - & - & - \\
\hline 7 & Luo et al. 4 & 2017 & 48 & M & - & Y & - & - & - & - & - & - & - & - & - & - \\
\hline 9 & Chigurupati et al. (5) & 2017 & 39 & $\mathrm{~F}$ & - & Y & Y & $\mathrm{Y}$ & $\mathrm{Y}$ & - & AV block & - & - & - & Diastolic/4/-/aortic & HTN \\
\hline 10 & Giambruno et al. (17) & 2016 & 61 & $\mathrm{~F}$ & Y & - & - & - & - & - & - & - & - & - & $\mathrm{Y}$ & - \\
\hline 11 & Prifti et al. (18) & 2016 & 52 & $\mathrm{~F}$ & - & Y & - & - & - & ST & - & - & - & IIII & - & - \\
\hline 12 & Sato et al. (19) & 2016 & 75 & M & - & - & - & $\mathrm{Y}$ & - & $\mathrm{AF}$ & - & - & - & - & - & HTN \\
\hline 13 & Qian et al. (12) & 2016 & 60 & $\mathrm{~F}$ & - & Y & - & - & - & - & - & - & Chest tightness & - & Early diastolic/-/soft/- & - \\
\hline 14 & Karvounaris et al. (20) & 2015 & 63 & $\mathrm{~F}$ & - & Y & - & - & - & ST & LBBB & - & Cardiogenic shock & - & Systolic/3/-/- & - \\
\hline 15 & Gong et al. (21) & 2015 & 45 & M & - & $\mathrm{Y}$ & - & - & - & - & - & - & - & - & Diastolic////L 2nd-3rd intercostal space & - \\
\hline 16 & Chikkabasavaiah et al. (22) & 2014 & 21 & M & - & - & - & - & - & - & - & - & Tonic clonic seizure & - & Early diastolic/////L upper parasternal & - \\
\hline 17 & Ogiwara et al. (23) & 2013 & 61 & $\mathrm{~F}$ & - & - & - & - & - & - & - & Y & - & - & - & - \\
\hline 18 & Schönrath et al. (24) & 2013 & 67 & M & - & Y & $\mathrm{Y}$ & - & - & - & - & - & - & - & - & - \\
\hline 19 & Minagawa et al. (25) & 2013 & 70 & M & - & - & - & - & - & - & RBBB & - & - & - & Systolic ejection/-I//L upper parasternal & HTN \\
\hline 20 & Lu et al. (26) & 2013 & 52 & M & - & - & - & - & - & $\mathrm{AF}$ & - & - & Chest discomfort & - & Diastolic/3/regurgitant/L sternal border & HTN, smoker \\
\hline 21 & Hu et al. (27) & 2013 & 66 & $\mathrm{~F}$ & - & - & - & Y & - & - & - & - & - & - & - & - \\
\hline 22 & Jouni et al. (28) & 2012 & 78 & M & - & Y & $\mathrm{Y}$ & - & - & - & - & - & - & - & Diastolic///-/-I & $\begin{array}{c}\text { HTN, } \\
\text { dyslipidemia, } \\
\text { OSA }\end{array}$ \\
\hline 23 & Yagoub et al. (29) & 2012 & 56 & M & Y & - & - & - & - & - & - & - & - & - & Y & - \\
\hline 24 & Saritas et al. (30) & 2012 & 75 & M & - & - & - & - & $\mathrm{Y}$ & - & - & - & - & - & - & - \\
\hline 25 & Altarabsheh et al. (32) & 2011 & 50 & $\mathrm{~F}$ & - & - & - & - & - & - & - & - & Chronic cough & - & - & - \\
\hline 26 & Gupta et al. (33) & 2010 & 56 & $\mathrm{~F}$ & - & $\mathrm{Y}$ & - & - & - & - & - & - & - & - & - & - \\
\hline 27 & Sohal et al. (34) & 2010 & 84 & M & - & - & - & - & $\mathrm{Y}$ & - & - & - & - & - & - & - \\
\hline 28 & Rosu et al. (35) & 2010 & 72 & M & - & $\mathrm{Y}$ & - & - & - & - & - & - & - & - & - & - \\
\hline 29 & Gunay et al. (36) & 2010 & 36 & M & - & - & - & - & - & - & - & - & Signs of TS & - & - & - \\
\hline 30 & Tang and Liu (37) & 2010 & 56 & - & - & - & - & - & - & - & - & - & - & - & - & - \\
\hline 31 & Bhat et al. (38) & 2009 & 35 & $\mathrm{~F}$ & - & - & $\mathrm{Y}$ & - & - & - & - & - & - & $\|$ & - & - \\
\hline 32 & Matteucci et al. (39) & 2009 & 54 & $\mathrm{~F}$ & - & - & - & - & Y & - & . & - & - & $\|$ & - & HTN \\
\hline
\end{tabular}


Table 1 (continued)

\begin{tabular}{|c|c|c|c|c|c|c|c|c|c|c|c|c|c|c|c|c|}
\hline \multirow{2}{*}{ Patient No } & \multirow{2}{*}{ Reference } & \multirow{2}{*}{ Year } & \multirow{2}{*}{ Age } & \multirow{2}{*}{ Sex } & \multicolumn{8}{|c|}{ Clinical presentation } & \multirow{2}{*}{ Others } & \multirow{2}{*}{ NYHA Class } & \multirow{2}{*}{ Murmur (timing/grade/quality/location) } & \multirow{2}{*}{ Comorbidities } \\
\hline & & & & & Asymptomatic & Dyspnea & Chest pain & Palpitation & Syncope & Arrhythmia & Conduction defect & $\mathrm{MI}$ & & & & \\
\hline 33 & Michiels et al. (40) & 2009 & 75 & M & - & $\mathrm{Y}$ & - & $\mathrm{Y}$ & - & - & - & - & - & - & - & - \\
\hline 34 & Ravindranath et al. (41) & 2009 & 35 & $\mathrm{~F}$ & - & $\mathrm{Y}$ & $\mathrm{Y}$ & $\mathrm{Y}$ & - & - & - & - & - & - & - & - \\
\hline 35 & Darabian et al. (42) & 2009 & 32 & $\mathrm{~F}$ & - & $\mathrm{Y}$ & - & - & - & - & - & - & - & - & /-///blowing/L upper sternal edge & - \\
\hline 36 & Sasaki et al. (43) & 2009 & 56 & M & - & - & - & - & - & - & - & - & - & - & - & - \\
\hline 37 & Yang et al. (44) & 2008 & 69 & M & Y & - & - & - & - & PAC, PVC & AV block & - & - & - & $\begin{array}{l}\text { Systolic ejection//2/-LL sternal border, 2nd and } \\
\text { 3rd intercostal space }\end{array}$ & HTN \\
\hline 38 & Fukui et al. (45) & 2008 & 38 & $\mathrm{~F}$ & Y & - & - & - & - & - & - & - & - & - & Diastolic/-/-/-I & - \\
\hline 39 & Klein et al. (46) & 2008 & 58 & $\mathrm{~F}$ & - & - & - & - & - & - & - & - & Chest pressure & - & - & - \\
\hline 40 & Zannis et al. (47) & 2007 & 24 & M & - & - & $\mathrm{Y}$ & $\mathrm{Y}$ & - & - & AV block, RBBB, LBBB & - & Exertional intolerance & - & - & - \\
\hline 41 & Vermeulen et al. (48) & 2006 & 81 & $\mathrm{~F}$ & - & - & $\mathrm{Y}$ & - & - & - & - & - & Fever & - & - & HTN, DM \\
\hline 42 & Yilik et al. (49) & 2006 & 29 & M & - & $\mathrm{Y}$ & - & - & - & $\mathrm{AF}$ & - & - & - & - & - & Smoker \\
\hline 43 & Joshi et al. (50) & 2006 & 78 & M & - & - & $\mathrm{Y}$ & - & - & $\mathrm{AF}$ & - & - & Dizziness & - & Systolic ejection/-/-/pulmonic & - \\
\hline 44 & Joshi et al. (50) & 2006 & 65 & M & - & - & - & - & - & - & - & - & - & - & $\mathrm{Y}$ & - \\
\hline 45 & Shin et al. (51) & 2005 & 35 & $\mathrm{~F}$ & - & - & $\mathrm{Y}$ & - & - & - & - & $\mathrm{Y}$ & Cardiogenic shock & - & - & - \\
\hline 46 & Mookadam et al. (52) & 2005 & 76 & M & - & $\mathrm{Y}$ & - & - & $\mathrm{Y}$ & SB & - & - & Orthopnea, peripheral edema & - & Systolic ejection/1/-/base & HTN \\
\hline 47 & Akashi et al. (53) & 2005 & 62 & $\mathrm{~F}$ & $\mathrm{Y}$ & - & - & - & - & - & AV block & - & - & - & Systolic ejection/-/-/L parasternal & - \\
\hline 48 & Sharda et al. (54) & 2004 & 38 & $\mathrm{~F}$ & - & - & $\mathrm{Y}$ & $\mathrm{Y}$ & - & - & - & $\mathrm{Y}$ & - & - & Systolic ejection/3/-/L 3rd intercostal space & - \\
\hline 50 & Banerjee and Jagasia (56) & 2002 & 75 & M & - & - & - & - & - & - & - & - & - & - & Diastolic/2/-/R upper sternal border & - \\
\hline 51 & Lijoi et al. (57) & 2002 & 75 & $\mathrm{~F}$ & - & - & $\mathrm{Y}$ & - & - & - & - & - & Myocardial ischemia & - & - & HTN, smoker \\
\hline 52 & Rhew et al. (58) & 2001 & 61 & M & - & - & - & - & - & PAC & AV block, RBBB & - & - & - & Systolic/5/-/L sternal border and pulmonic & - \\
\hline 53 & Tsukui et al. (59) & 2000 & 63 & $\mathrm{~F}$ & - & $\mathrm{Y}$ & - & $\mathrm{Y}$ & - & $\mathrm{AF}$ & - & - & - & - & - & - \\
\hline
\end{tabular}


Arrhythmias (21\%,11/53 cases) and conduction abnormalities (13\%, 7/53 cases) were commonly reported in patients with unruptured SVAs. The most common arrhythmia observed was atrial fibrillation ( $9 \%, 5 / 53$ cases). Other arrhythmias described include sinus tachycardia (4\%, $2 / 53$ cases), sinus bradycardia ( $2 \%, 1 / 53$ cases), premature atrial contractions ( $4 \%, 2 / 53$ cases), premature ventricular contractions ( $2 \%, 1 / 53$ cases), and the presence of ectopic beats ( $2 \%, 1 / 53$ cases). In terms of conduction issues, firstdegree atrioventricular block was reported in $9 \%$ of patients (5/53 cases), followed by right bundle branch block ( $6 \%$, $3 / 53$ cases) and left bundle branch block (4\%, 2/53 cases).

Comorbidities were mentioned in $23 \%$ of patients (12/53 cases). These include hypertension (19\%, 10/53 cases), obstructive sleep apnea ( $2 \%, 1 / 53$ cases), smoking ( $8 \%, 4 / 53$ cases), dyslipidemia ( $2 \%, 1 / 53$ cases), and type II diabetes ( $2 \%, 1 / 53$ cases).

\section{Diagnosis}

\section{Imaging modalities}

Echocardiography (92\%, 49/53 cases), CT (60\%, 32/53 cases), and angiography (60\%,32/53 cases) were the most frequently used imaging modalities for the diagnosis of unruptured SVAs (Table 2). Transthoracic echocardiography (TTE) $(83 \%, 44 / 53$ cases) offered a non-invasive initial assessment of morphology, location, and origin of an SVA. Transesophageal echocardiography (42\%, 22/53 cases) was performed in cases of diagnostic uncertainty, or if involvement of the surrounding structures was not well delineated on TTE. Three-dimensional echocardiography allowed for the reconstruction of SVAs and associated lesions with excellent resolution ( $2 \%, 1 / 53$ cases). Cardiac catheterization confirmed the diagnosis, the hemodynamic significance of the lesion, and associated cardiac abnormalities. Coronary angiography (30\%, 16/53 cases), CT angiography (CTA) (25\%, 13/53 cases), aortic angiography $(23 \%, 12 / 53$ cases), ventricular angiography ( $6 \%, 3 / 53$ cases), and aortic CTA $(2 \%, 1 / 53$ cases) have all been used previously as well. CT and MRI $(11 \%, 6 / 53$ cases) have been used as supplemental or confirmatory tests. In some cases, the diagnosis of unruptured SVA is made intra-operatively ( $2 \%, 1 / 53$ cases).

\section{Aneurysm characteristics from imaging studies}

The majority of unruptured SVA cases involved one SV (83\%, 44/53 cases), although there have been cases that involved two or all three SV's (17\%, 9/53 cases) (Table 2).
SVAs originated predominantly from the RSV (64\%, 34/53 cases), followed by the non-coronary SV (NSV) (36\%, $19 / 53$ cases) and the left SV (LSV) (28\%, 15/53 cases). A thrombus was present in $34 \%$ of the cases (18/53 cases). Eight percent (4/53 cases) of the reported unruptured SVAs were described as being calcified.

Unruptured SVAs may cause structural and functional anomalies of surrounding cardiac structures. Associated aortic problems such as dilation of the annulus ( $6 \%, 3 / 53$ cases) and ascending aorta ( $4 \%, 2 / 53$ cases) have both been described in the context of unruptured SVAs. Large unruptured SVAs can have a mass effect on adjacent cardiac chambers, outflow tracts and great vessels, thereby distorting, obstructing or compressing them $(58 \%, 31 / 53$ cases). The right ventricle (RV) (36\%, 19/53 cases), RV outflow tract $(30 \%, 16 / 53$ cases), and right atrium (19\%, $10 / 53$ cases) were most commonly affected, consistent with the observation that the majority of unruptured SVAs arise from the RSV. Although less common, compression of left sided structures such as the left atrium (9\%, $5 / 53$ cases), left ventricle $(\mathrm{LV})(6 \%, 3 / 53$ cases), and $\mathrm{LV}$ outflow tract $(2 \%$, $1 / 53$ cases) was also reported in the presence of unruptured SVAs, with aortic root compression and pulmonary artery constriction uncommonly reported ( $2 \%, 1 / 53$ cases).

Valvular issues were described in $60 \%$ of the cases $(32 / 53$ cases), with aortic regurgitation being the most common (49\%, 26/53 cases). Mitral regurgitation (15\%, 8/53 cases), tricuspid regurgitation $(8 \%, 4 / 53$ cases) and tricuspid annular deformity ( $2 \%, 1 / 53$ cases) comprise the rest of the valvular complications. Unruptured SVAs can affect the coronary arteries by displacing, compressing, obstructing or stretching them $(34 \%, 18 / 53$ cases $)$. The right coronary artery (19\%, 10/53 cases) and left main coronary artery (15\%, 8/53 cases) were predominantly affected. Complications involving other coronary arteries such as the posterior descending artery $(2 \%, 1 / 53$ cases), posterior left ventricular artery ( $2 \%, 1 / 53$ cases), left anterior descending ( $4 \%, 2 / 53$ cases), and left circumflex artery ( $2 \%, 1 / 53$ cases) have also been described.

\section{Histopathology}

Histopathological information was available in 18 case reports. Of these cases, inflammatory causes, which manifested as either inflammatory cell infiltration or nonspecific chronic inflammatory changes, were reported in $33 \%$ of patients (6/18 cases). Degenerative changes in the tunica media of the aneurysm wall were found in $44 \%$ of 


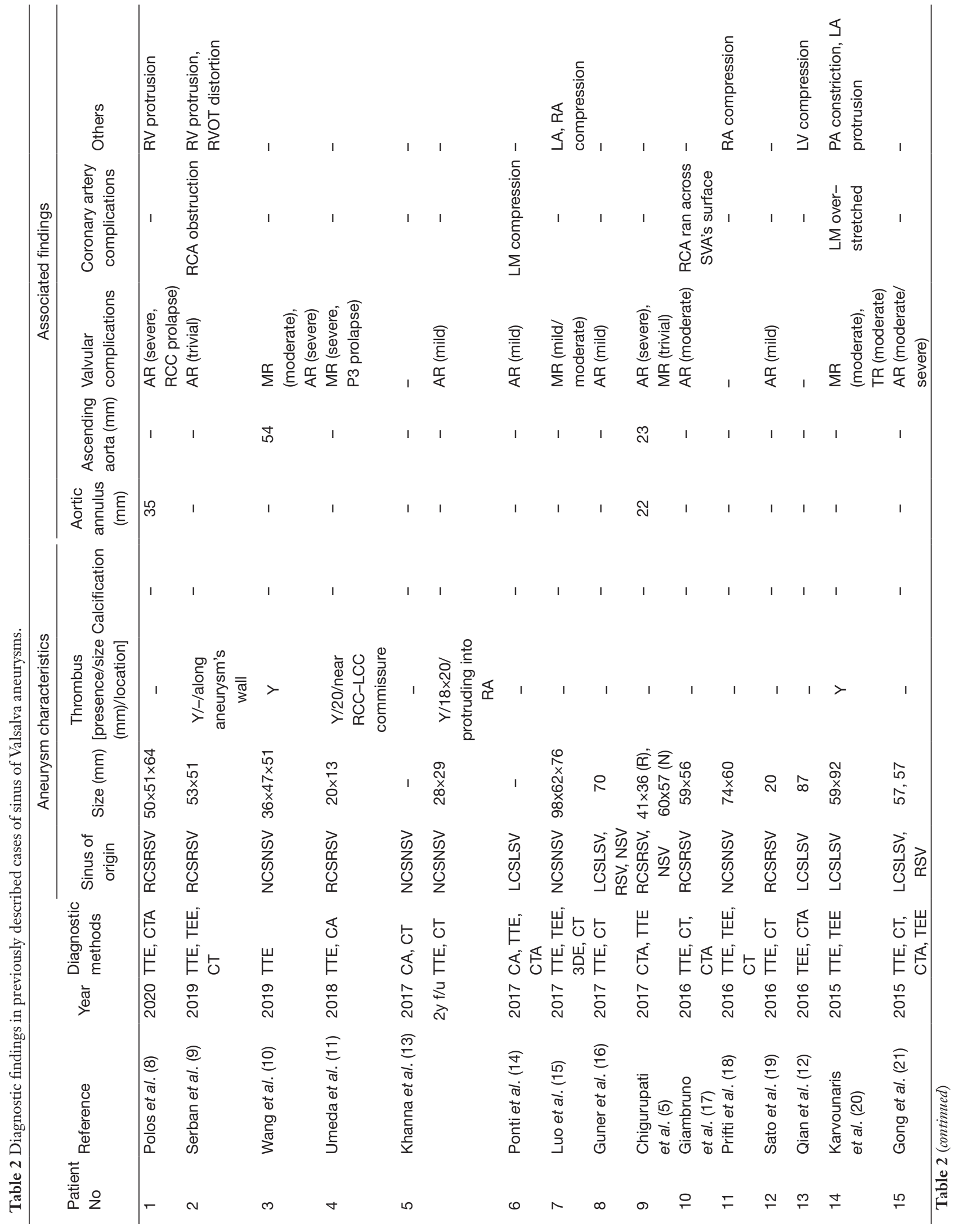




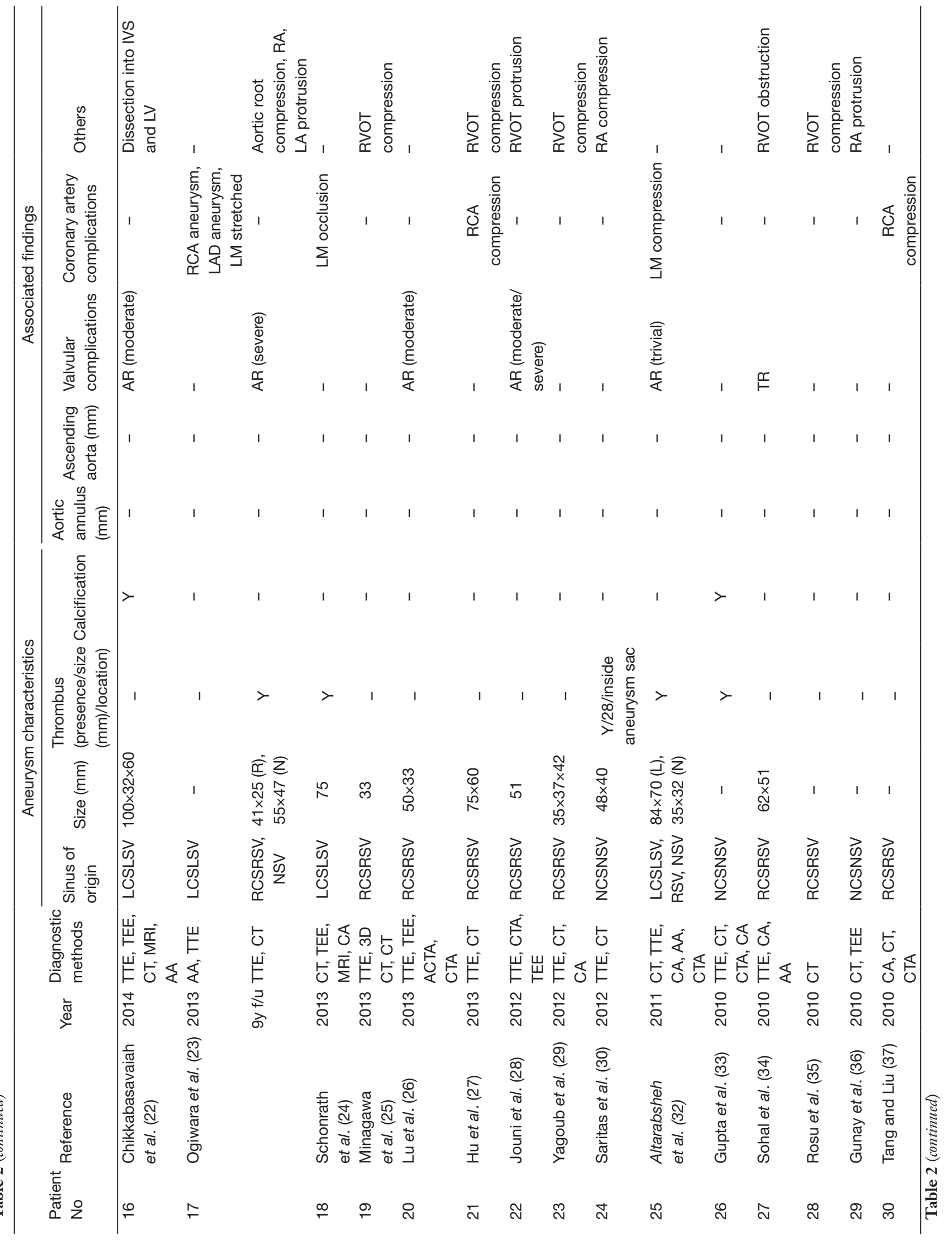




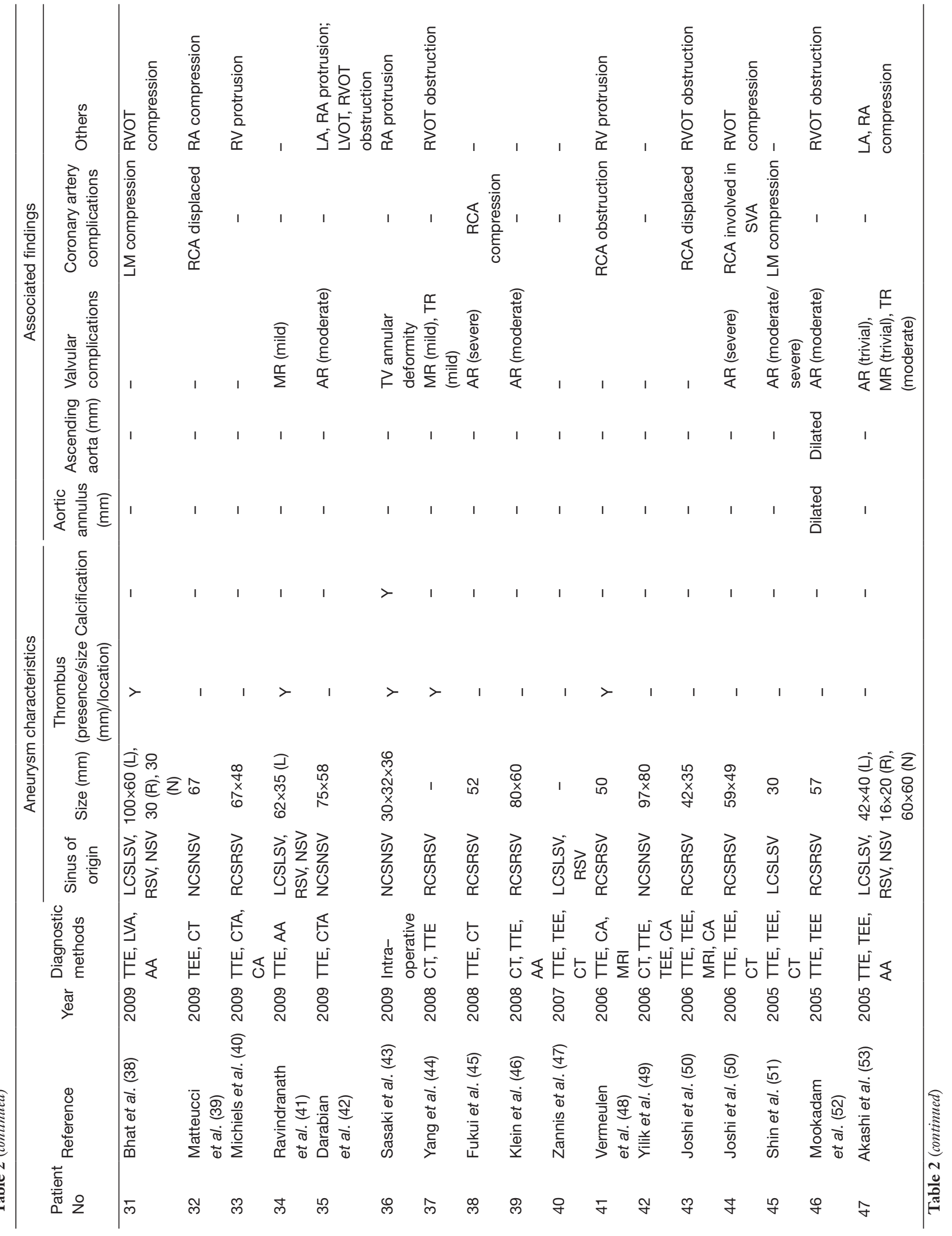




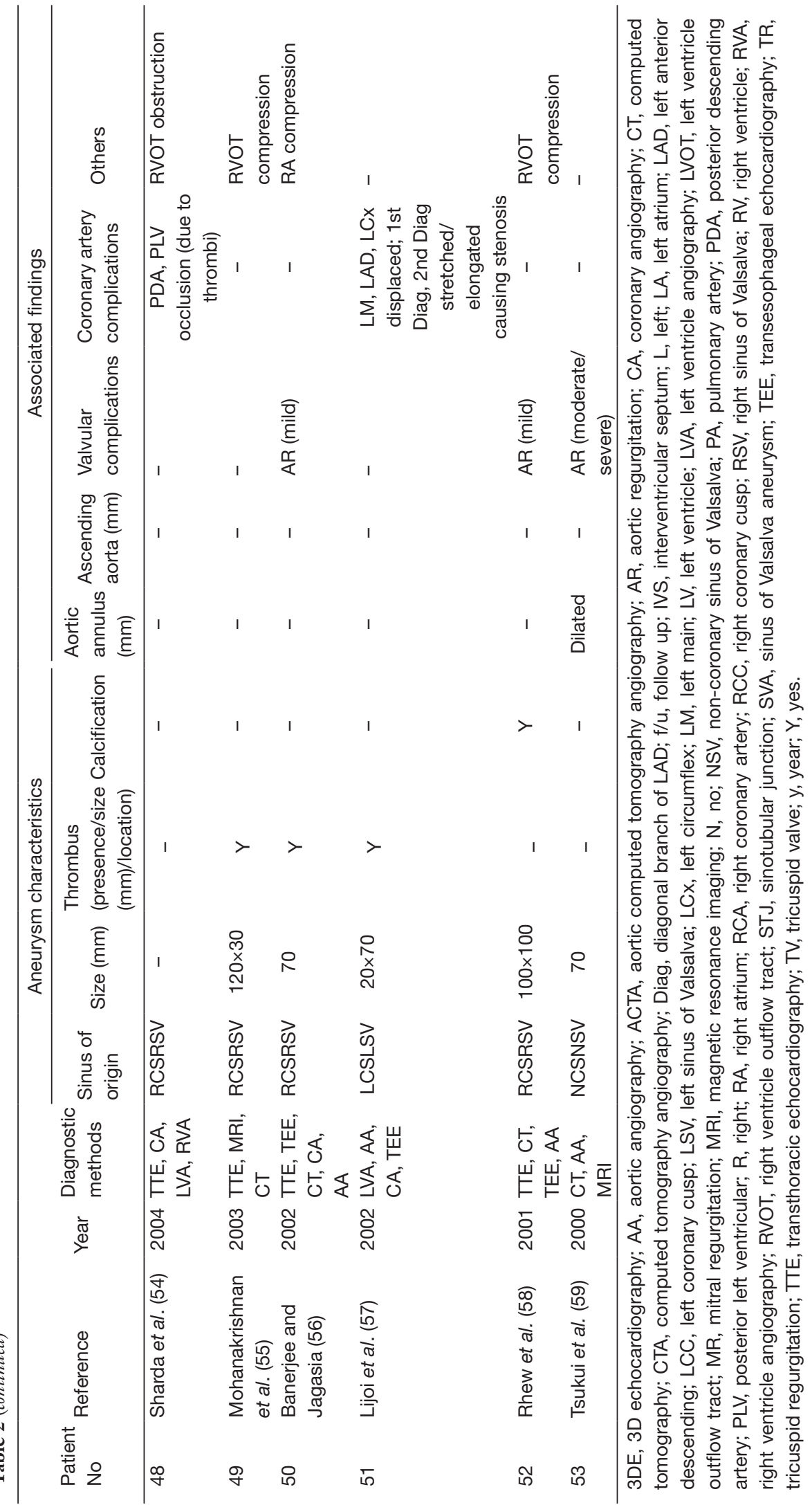


cases (8/18 cases), with mucoid deposits noted in $39 \%$ of them (7/18 cases). Damage, deficiency or absence of elastic fibers was present in $28 \%$ of the reported cases (5/18 cases). Atherosclerotic degeneration was also noted in $6 \%$ of patients ( $1 / 18$ cases).

\section{Surgical management and outcomes}

All 53 cases (100\%) of unruptured SVAs were managed surgically (Table 3). One patient was initially managed conservatively with medical follow-up and TTE every 6 months. However, at the two-year follow-up, the unruptured SVA was shown to increase in size, with thrombus formation and mass effect on surrounding structures, necessitating surgical intervention.

\section{Indications for treatment}

The rationale behind surgical treatment of unruptured SVAs was mentioned in 21 cases (Table 3). Among these cases, the majority of unruptured SVAs were surgically managed to as a preventative measure to avoid complications such as aneurysm rupture or thrombus formation (38\%, 8/21 cases with information on treatment indication). Aneurysm size, either large or rapidly increasing size, was an indication for surgical treatment in $29 \%$ of patients (6/21 cases). Other indications included symptomatic clinical presentation (14\%, $3 / 21$ cases), presence of a thrombus $(14 \%, 3 / 21$ cases), observation of a mass effect on adjacent structures (14\%, $3 / 21$ cases), and recurrent aneurysm after surgical resection $(5 \%, 1 / 21$ cases).

\section{Surgical approaches}

Surgical approaches for the management of unruptured SVAs were mainly dependent on aneurysm size and the presence of associated lesions (Table 3). Small aneurysms can be repaired by direct closure of the aneurysmal orifice (4\%, 2/53 cases). For larger aneurysms, patch repair was preferred as direct closure may distort the anatomy of the aortic root $(66 \%, 35 / 53$ cases). The presence of valvular issues generally requires valve replacement/repair or annular repair. Aortic valve (AV) replacement/repair was performed in $36 \%$ of patients (19/53 cases), AV annuloplasty in $6 \%$ ( $3 / 53$ cases), mitral valve (MV) replacement/repair in $8 \%$ (4/53 cases), MV annulus reconstruction in $2 \%(1 / 53$ cases), and tricuspid valve repair in $2 \%$ of patients (1/53 cases). If the involvement of the unruptured SVA was extensive and the aortic root appeared distorted, full aortic root replacement $(23 \%, 12 / 53$ cases $)$ or ascending aorta replacement (4\%, 2/53 cases) may be necessary. Coronary artery bypass grafting was performed in cases where one or more coronary arteries were compromised due to mass effect of the aneurysms (17\%, 9/53 cases).

\section{Operative outcomes}

The majority of operations for unruptured SVAs were uneventful (96\%, 51/53 cases) (Table 3). In-hospital mortality was reported in two patients ( $4 \%$ of cases), one intraoperative and the other within 48 hours post-operation due to multi-organ failure. Patients spent 4 to 21 days in hospital after surgical management of unruptured SVAs.

\section{Prognosis}

Follow-up, ranging from five days to nine years in duration, was reported in 31 cases (Table 3). The majority of these cases were asymptomatic and showed obliteration of the aneurysm as well as restoration of aortic root anatomy and valvular function $(94 \%, 29 / 31)$. One patient needed percutaneous intervention at follow-up due to a detected leak, and the aneurysm only showed partial thrombosis after surgical repair (14). At the two-month follow-up post percutaneous intervention, CTA showed almost complete thrombosis of the aneurysm lumen. One patient was reported to have recurrence of SVA at nine-years of followup, which required surgical intervention (23).

\section{Limitations}

Our study is subject to a number of limitations. Given that our review article only includes published articles, it may be subject to publication bias. In addition, in our efforts to provide a contemporary review by limiting the inclusion criteria to articles published after the year 2000, we may have excluded other less contemporary, but relevant studies. Heterogeneity in study populations is evident. We cannot account for centre-specific practices, threshold for intervention, and postoperative management that may affect the therapeutic strategies and patient outcomes of unruptured SVAs.

\section{Conclusions}

Unruptured SVAs are rare entities that can cause significant morbidity and devastating consequences if ruptured. Advances in cardiac imaging have made early recognition and diagnosis of unruptured SVAs possible in a less invasive manner in recent years. Regardless, the diagnosis of 
Table 3 Treatment approaches and outcomes of sinus of Valsalva aneurysms

\begin{tabular}{|c|c|c|c|c|c|c|c|c|c|c|}
\hline Patient No & Reference & Year & Approach & $\begin{array}{l}\text { Indication for } \\
\text { treatment }\end{array}$ & Method of repair & Complications & Pathology/histology & $\begin{array}{l}\text { Hospital } \\
\text { stay (d) }\end{array}$ & $\begin{array}{l}\text { Follow-up } \\
\text { time }\end{array}$ & Follow-up findings \\
\hline 1 & Polos et al. (8) & 2020 & Surgery & $\begin{array}{l}\text { Clinical } \\
\text { presentation }\end{array}$ & $\begin{array}{l}\text { Direct closure of the opening of aneurysm, AV repair, AV annuloplasty, } \\
\text { aortic root replacement }\end{array}$ & - & - & - & $1 \mathrm{~m}$ & TTE-competent AV, no AR \\
\hline 2 & Serban et al. (9) & 2019 & Surgery & Aneurysm size & Resection and patch repair of aneurysm, CABG×1 (SVG to RCA) & - & $\begin{array}{l}\text { Elastic fibers deficiency, mucoid } \\
\text { deposits }\end{array}$ & 11 & $1 \mathrm{~m}$ & Asymptomatic; TE, TEE, CT-normal AV, aortic root and ascending aorta \\
\hline 3 & Wang et al. (10) & 2019 & Surgery & $\begin{array}{l}\text { Aneurysm size, } \\
\text { involvement } \\
\text { of adjacent } \\
\text { structures }\end{array}$ & $\begin{array}{l}\text { Resection of aneurysm, MVR, MV annulus reconstruction, AVR, } \\
\text { ascending aorta replacement }\end{array}$ & - & $\begin{array}{l}\text { Mucoid degeneration, abscess } \\
\text { formation, inflammatory cells } \\
\text { infiltration }\end{array}$ & - & - & TTE-functioning AV and MV; CTA-restoration of normal aortic root anatomy \\
\hline 4 & Umeda et al. (11) & 2018 & Surgery & $\begin{array}{l}\text { Prevent systemic } \\
\text { embolization }\end{array}$ & cPatch repair of aneurysm, MV repair & - & $\begin{array}{l}\text { Fresh thrombus with fibrin, red } \\
\text { blood cells, white blood cells, } \\
\text { platelets }\end{array}$ & - & - & - \\
\hline \multirow[t]{2}{*}{5} & Khanna et al. (13) & 2017 & $\begin{array}{l}\text { Medical f/u, } \\
\text { TE } q 6 \mathrm{~m}\end{array}$ & - & - & - & - & - & $2 y$ & $\begin{array}{l}\text { TTE, CT-enlarged SVA originated from NSV }(28 \times 29 \mathrm{~mm}) \text {, with thrombus }(18 \times 20 \mathrm{~mm}) \text {, } \\
\text { protruding into RA; mild AR }\end{array}$ \\
\hline & & $2 y \mathrm{f} / \mathrm{u}$ & Surgery & $\begin{array}{l}\text { Prevent systemic } \\
\text { embolization }\end{array}$ & cResection and patch repair of aneurysm & - & - & - & - & - \\
\hline \multirow[t]{2}{*}{6} & Ponti et al. (14) & 2017 & Surgery & - & $\begin{array}{l}\text { Patch repair of aneurysm, CABGX3 (LIMA to LAD, SVG to LCX, SVG to } \\
\text { ramus) }\end{array}$ & - & - & - & - & $\begin{array}{l}\text { TTE, CTA-leak at anterior border of the patch used to close the aneurysm, only partial } \\
\text { thrombosis of aneurysm; readmitted for percutaneous procedure }\end{array}$ \\
\hline & & $f / u \quad F$ & Percutaneous & $\begin{array}{l}\text { sLeak detected } \\
\text { and only partial } \\
\text { thrombosis of } \\
\text { aneurysm post } \\
\text { surgical repair }\end{array}$ & $\begin{array}{l}\text { Selective catheterization through the residual neck, implantation of } \\
\text { Amplazer septal occluder }\end{array}$ & - & - & - & $2 \mathrm{~m}$ & CTA-almost complete thrombosis of aneurysm lumen \\
\hline 8 & Guner et al. (16) & 2017 & Surgery & - & Cabrol procedure & - & - & - & - & - \\
\hline 9 & Chigurupati et al. (5) & 2017 & Surgery & - & Modified Bentall procedure & - & - & - & - & - \\
\hline 10 & Giambruno et al. (17) & 2016 & Surgery & Aneurysm size & Resection and patch repair of aneurysm, AVR, CABGx1 (SVG to RCA) & - & $\begin{array}{l}\text { No specific pathologic conditions/ } \\
\text { infective processes }\end{array}$ & 5 & $1 \mathrm{y}$ & Asymptomatic; $T \pi E-$ functioning $A V$ and good biventricular function \\
\hline 11 & Prifti et al. (18) & 2016 & Surgery & Prevent rupture & Resection and patch repair of aneurysm & - & $\begin{array}{l}\text { Mucoid deposits, loss of elastic } \\
\text { fibers, eosinophilic infiltration }\end{array}$ & - & $1 \mathrm{~m}, 1 \mathrm{y}$ & $1 \mathrm{~m}$ : CTA - complete thrombosed cavity of the previous aneurysm; $1 \mathrm{y}: \mathrm{TE}-$ mild AR \\
\hline 12 & Sato et al. (19) & 2016 & Surgery & Aneurysm size & Patch repair of aneurysm & - & - & - & $\begin{array}{c}1 \mathrm{w}, 3 \mathrm{~m}, 1 \\
\mathrm{y}\end{array}$ & $\begin{array}{l}1 \text { 1w: CT-no leakage of contrast medium into the isolated aneurysm; } 3 \mathrm{~m}: \text { TTE, CT- } \\
\text { aneurysm size reduction, heterogeneous echogenicity, blood flow in the aneurysm, } \\
\text { thrombus formation, a recurrent fistula, partial recanalization between the patched } \\
\text { aneurysm and the R SOV; 1y: TTE-significant aneurysm size reduction, no shunt flow }\end{array}$ \\
\hline 13 & Qian et al. (12) & 2016 & Surgery & $\begin{array}{l}\text { Prevent } \\
\text { thrombus } \\
\text { formation and } \\
\text { rupture }\end{array}$ & Resection of aneurysm, reconstruction of coronary arteries & - & $\begin{array}{l}\text { Breakage of the intimal elastic } \\
\text { fiber, lymphocytic infiltration, } \\
\text { fibroplastic proliferation, } \\
\text { calcification foci and hyaline } \\
\text { degeneration with cystic } \\
\text { degeneration of the tunica media }\end{array}$ & - & - & - \\
\hline 14 & $\begin{array}{l}\text { Karvounaris } \\
\text { et al. (20) }\end{array}$ & 2015 & Surgery & $\begin{array}{l}\text { Clinical } \\
\text { presentation }\end{array}$ & Bentall procedure & Dead & - & - & - & - \\
\hline 15 & Gong et al. (21) & 2015 & Surgery & - & AV annuloplasty, aortic sinus repair, coronary artery ostia graft & - & - & - & - & - \\
\hline
\end{tabular}


Table 3 (continued)

\begin{tabular}{|c|c|c|c|c|c|c|c|c|c|c|}
\hline Patient No & Reference & Year & Approach & $\begin{array}{l}\text { Indication for } \\
\text { treatment }\end{array}$ & Method of repair & Complications & Pathology/histology & $\begin{array}{l}\text { Hospital } \\
\text { stay (d) }\end{array}$ & $\begin{array}{l}\text { Follow-up } \\
\text { time }\end{array}$ & Follow-up findings \\
\hline 16 & $\begin{array}{l}\text { Chikkabasavaiah } \\
\text { et al. (22) }\end{array}$ & 2014 & Surgery & - & $\begin{array}{l}\text { A sandwich device fabricated with Gortex and Teflon felt was used to } \\
\text { close the aneurysm (Trusler's repair), gel foam was injected to facilitate } \\
\text { clot formation in the aneurysm, AV subcommissural annuloplasty }\end{array}$ & - & - & - & $1 \mathrm{~m}$ & Asymptomatic; $\Pi E$-clot formation within aneurysm, minimal AR \\
\hline \multirow[t]{2}{*}{17} & Ogiwara et al. (23) & 2013 & Surgery & - & $\begin{array}{l}\text { Resection and patch repair of aneurysm, LM reimplanted using button } \\
\text { technique, CABGx2 (SVG to LAD, SVG to RCA-IMA's were too small } \\
\text { for bypass grafting) }\end{array}$ & - & Mild atherosclerotic degeneration & - & $9 y$ & $\begin{array}{l}\text { TEE, CT-recurrent SVA's originated from RSV and NSV; severe AR; aortic root, RA and } \\
\text { LA compression }\end{array}$ \\
\hline & & $9 y$ f/u & Surgery & $\begin{array}{l}\text { Recurrent } \\
\text { aneurysms }\end{array}$ & AVR, aortic root replacement & $\begin{array}{l}\text { Unsuccessful } \\
\text { separation from } \\
\text { bypass, cardiac } \\
\text { output was not } \\
\text { maintained, } \\
\text { dead within } 48 \mathrm{~h} \\
\text { post-operative }\end{array}$ & & - & - & - \\
\hline 18 & Schonrath et al. (24) & 2013 & Surgery & - & $\begin{array}{l}\text { Resection of aneurysm, aortic root replacement, CABGx2 (LIMA to } \\
\text { LAD, RIMA to LCx) }\end{array}$ & - & - & - & - & - \\
\hline 19 & Minagawa et al. (25) & 2013 & Surgery & Prevent rupture & Patch repair of aneurysm & - & - & 21 & $2 \mathrm{w}, 4 \mathrm{~m}$ & $\begin{array}{l}2 \mathrm{~W} \text { : TTE-RVOT flow } 3.1 \mathrm{~m} / \mathrm{s} ; 4 \mathrm{~m}: \text { TEE, CT - further improved RVOT flow, no AR, no } \\
\text { leakages to SVA sac, size reduction of the SVA sac, improvement of RVOT obstruction, } \\
\text { RVOT flow } 0.6 \mathrm{~m} / \mathrm{s}\end{array}$ \\
\hline 20 & Lu et al. (26) & 2013 & Surgery & - & Bentall procedure, modified Maze III procedure (for AF) & - & $\begin{array}{l}\text { Diffuse mucin deposits in the } \\
\text { media of the aneurysm, absence } \\
\text { of medial elastic fibers }\end{array}$ & - & $2.5 \mathrm{~m}$ & Unremarkable \\
\hline 21 & Hu et al. (27) & 2013 & Surgery & - & $\begin{array}{l}\text { Aneurysm repaired with scalloped patch of wider diameter than the } \\
\text { distance between the sinotubular ridge superiorly and the bases of } \\
\text { aortic annulus inferiorly, creating a pseudosinus. An aortic flap was } \\
\text { tailored around the ostium of the RCA and sewn to the patch (the flap } \\
\text { base was the normal aortic wall, it's free edge was corresponding to } \\
\text { the remant edge of the patch) }\end{array}$ & - & $\begin{array}{l}\text { Mucoid degeneration in the wall of } \\
\text { the aneurysm }\end{array}$ & - & - & CTA, TTE-functioning AV, no AR, preserved aortic geometry \\
\hline 22 & Jouni et al. (28) & 2012 & Surgery & - & Patch repair of aneurysm, AVR & - & - & - & - & - \\
\hline 23 & Yagoub et al. (29) & 2012 & Surgery & - & Valve-sparing repair of aneurysm & - & - & - & - & TTE-obliteration of SVA, functioning AV \\
\hline 24 & Saritas et al. (30) & 2012 & Surgery & - & Patch repair of aneurysm, AVR, CABG $\times 3$ & - & - & - & - & - \\
\hline 25 & $\begin{array}{l}\text { Altarabsheh } \\
\text { et al. (32) }\end{array}$ & 2011 & Surgery & - & AVR, aortic root replacement, reimplantation of coronary buttons & - & - & - & - & - \\
\hline 26 & Gupta et al. (33) & 2010 & Surgery & - & $\begin{array}{l}\text { Resection of aneurysm, ascending aorta replacement, reimplantation of } \\
\text { R coronary button }\end{array}$ & - & - & - & - & - \\
\hline 27 & Sohal et al. (34) & 2010 & Surgery & - & Resection and patch repair of aneurysm & - & - & - & - & - \\
\hline 28 & Rosu et al. (35) & 2010 & Surgery & - & Patch repair of aneurysm, reimplantation of $\mathrm{R}$ coronary button & - & - & - & - & - \\
\hline 29 & Gunay et al. (36) & 2010 & Surgery & - & Resection and patch repair of aneurysm & - & - & - & - & - \\
\hline 30 & Tang and Liu (37) & 2010 & Surgery & - & Patch repair of aneurysm, AVR, CABG $\times 1$ (SVG to RCA) & - & - & 9 & - & - \\
\hline 31 & Bhat et al. (38) & 2009 & Surgery & - & Patch repair of aneurysm & - & Nonspecific chronic inflammation & - & $9 \mathrm{~m}$ & Asymptomatic; $\Pi \pi E-$ near normal dimensions of 3 sinuses, normal biventricular function \\
\hline 32 & Matteucci et al. (39) & 2009 & Surgery & Aneurysm size & Resection and patch repair of aneurysm & - & $\begin{array}{l}\text { Eosinophilic infiltration of } \\
\text { aneurrysmal wall }\end{array}$ & - & $1 \mathrm{~m}$ & Asymptomatic; no LVOT obstruction \\
\hline
\end{tabular}




\begin{tabular}{|c|c|c|c|c|c|c|c|c|c|c|}
\hline Patient No & Reference & Year & Approach & $\begin{array}{l}\text { Indication for } \\
\text { treatment }\end{array}$ & Method of repair & Complications & Pathology/histology & $\begin{array}{l}\text { Hospital } \\
\text { stay (d) }\end{array}$ & $\begin{array}{l}\text { Follow-up } \\
\text { time }\end{array}$ & Follow-up findings \\
\hline 33 & Michiels et al. (40) & 2009 & Surgery & - & Patch repair of aneurysm, reimplantation of $R$ coronary button & - & - & - & - & - \\
\hline 34 & $\begin{array}{l}\text { Ravindranath } \\
\text { et al. (41) }\end{array}$ & 2009 & Surgery & - & Patch repair of aneurysm & - & Nonspecific chronic inflammation & - & - & $\begin{array}{l}\text { TEE-near normal dimensions of all } 3 \text { sinuses, normal biventricular function, no regional } \\
\text { wall motion abnormalities }\end{array}$ \\
\hline 35 & Darabian et al. (42) & 2009 & Surgery & - & Resection and patch repair of aneurysm, AVR, MVR & - & - & - & $3 \mathrm{~m}$ & Unremarkable \\
\hline 36 & Sasaki et al. (43) & 2009 & Surgery & - & Patch repair of aneurysm, TV repair & - & $\begin{array}{l}\text { Aneurysmal sac filled with a } \\
\text { highly laminated and calcified } \\
\text { agglutinative thrombus, the } \\
\text { surface of the aneurysm contained } \\
\text { only a layer of elastic fibers }\end{array}$ & - & $1 \mathrm{y}$ & Unremarkable \\
\hline 37 & Yang et al. (44) & 2008 & Surgery & $\begin{array}{l}\text { Presence of } \\
\text { intraluminal } \\
\text { thrombus }\end{array}$ & Patch repair of aneurysm & - & - & - & - & TTE-normal aortic root, no AR \\
\hline 38 & Fukui et al. (45) & 2008 & Surgery & - & $\begin{array}{l}\text { Resection and patch repair of aneurysm, AVR, reimplantation of R } \\
\text { coronary button, reconstruction of RCA }\end{array}$ & - & $\begin{array}{l}\text { Diffusely necrotized aortic media, } \\
\text { severely destroyed elastic fiber of } \\
\text { the media }\end{array}$ & 21 & - & - \\
\hline 39 & Klein et al. (46) & 2008 & Surgery & - & $\begin{array}{l}\text { Aortic root replacement, reimplantation of } L \text { coronary button, } C A B G \times 1 \\
\text { (SVG to RAA) }\end{array}$ & - & - & 4 & - & - \\
\hline 40 & Zannis et al. (47) & 2007 & Surgery & $\begin{array}{l}\text { Aneurysm } \\
\text { size, aneurysm } \\
\text { extracardiac } \\
\text { extension }\end{array}$ & Patch repair of aneurysm & - & - & 8 & $11 \mathrm{~m}$ & Unremarkable \\
\hline 42 & Yilik et al. (49) & 2006 & Surgery & - & Resection and patch repair of aneurysm & - & $\begin{array}{l}\text { Mucoid degenaration of the tunica } \\
\text { media, no inflammatory change }\end{array}$ & - & $5 \mathrm{~d}, 3 \mathrm{~m}$ & TTE-normal aortic root, no AR \\
\hline 43 & Joshi et al. (50) & 2006 & Surgery & Prevent rupture & Patch repair of aneurysm & - & - & 5 & $1 \mathrm{y}$ & TTE-competent AV, no RVOT gradient \\
\hline 44 & Joshi et al. (50) & 2006 & Surgery & Prevent rupture & AVR, hemiroot replacement, reimplantation of $R$ coronary button & - & $\begin{array}{l}\text { Cystic medial necrosis of the } \\
\text { aortic wall with myxoid changes in } \\
\text { the valve tissue }\end{array}$ & 7 & $1 \mathrm{y}$ & $\begin{array}{l}\text { Asymptomatic; TTE-functioning AV, no AR, root diameter } 35 \mathrm{~mm} \text {, no residual aortic } \\
\text { aneurysm }\end{array}$ \\
\hline 45 & Shin et al. (51) & 2005 & Surgery & - & Patch repair of aneurysm, AVR & - & - & - & - & $\begin{array}{l}\text { TTE-normal LV wall motion, functioning AV; Multislice spiral CT-good coronary flow, } \\
\text { no compression }\end{array}$ \\
\hline 46 & Mookadam et al. (52) & 2005 & Surgery & - & Repair of aneurysm, $A V$ repair, resection of ventricular aneurysm & - & - & - & $6 y$ & Unremarkable \\
\hline 47 & Akashi et al. (53) & 2005 & Surgery & $\begin{array}{l}\text { Prevent } \\
\text { complications }\end{array}$ & Valve-sparing aortic root remodeling using Yacoub procedure & - & - & - & - & AA-no AR \\
\hline 48 & Sharda et al. (54) & 2004 & Surgery & - & Patch repair of aneurysm & - & - & - & - & TTE-unremarkable \\
\hline 49 & $\begin{array}{l}\text { Mohanakrishnan } \\
\text { et al. (55) }\end{array}$ & 2003 & Surgery & $\begin{array}{l}\text { Clinical } \\
\text { presentation }\end{array}$ & $\begin{array}{l}\text { Resection and patch repair of aneurysm, RVOT reconstruction using } \\
\text { pericardial patch }\end{array}$ & - & - & 8 & - & - \\
\hline 50 & $\begin{array}{l}\text { Banerjee and Jagasia } \\
\text { (56) }\end{array}$ & 2002 & Surgery & - & Resection and patch repair of aneurysm & - & - & - & - & - \\
\hline
\end{tabular}

Table 3 (continued) 
Table 3 (continued)

\begin{tabular}{|c|c|c|c|c|c|c|c|c|c|c|}
\hline Patient No & Reference & Year & Approach & $\begin{array}{l}\text { Indication for } \\
\text { treatment }\end{array}$ & Method of repair & Complications & Pathology/histology & $\begin{array}{l}\text { Hospital } \\
\text { stay (d) }\end{array}$ & $\begin{array}{l}\text { Follow-up } \\
\text { time }\end{array}$ & Follow-up findings \\
\hline 51 & Lijoi et al. (57) & 2002 & Surgery & - & Direct closure of the opening of aneurysm & - & - & - & $6 \mathrm{~m}$ & $\begin{array}{l}\text { Asymptomatic; TTE-normal aortic root, no AR, normal LV function; Thallium } \\
\text { scintigraphy, exercise stress test - no residual ischemia }\end{array}$ \\
\hline 52 & Rhew et al. (58) & 2001 & Surgery & $\begin{array}{l}\text { Prevent rupture, } \\
\text { relieve outflow } \\
\text { tract obstruction }\end{array}$ & Patch repair of aneurysm & - & - & - & - & - \\
\hline 53 & Tsukui et al. (59) & 2000 & Surgery & Prevent rupture & Resection and patch repair of aneurysm, AVR & - & $\begin{array}{l}\text { Mucoid degeneration of the tunica } \\
\text { media without inflammatory } \\
\text { changes }\end{array}$ & - & $10 \mathrm{~m}$ & Unremarkable \\
\hline
\end{tabular}

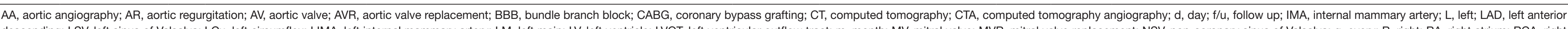

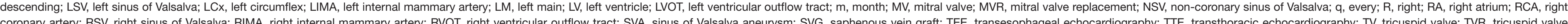
replacement; w, week; y, year. 
unruptured SVAs still requires a high index of suspicion, as patients can be asymptomatic or present with non-specific symptoms. Surgical repair remains the preferred method of treatment in order to prevent complications such as rupture or thrombus formation. Surgery should be prompted in patients with symptomatic, large, or rapidly expanding unruptured SVAs, as well as those unruptured SVAs that contain intraluminal thrombi, have a mass effect on surrounding structures, or are recurrent. Surgical outcomes are generally good with favourable prognosis and minimal recurrence.

\section{Acknowledgments}

Funding: None.

\section{Footnote}

Reporting Checklist: The authors have completed the Narrative Review reporting checklist. Available at http:// dx.doi.org/10.21037/jtd-20-2682

Conflicts of Interest: All authors have completed the ICMJE uniform disclosure form (available at http://dx.doi. org/10.21037/jtd-20-2682). The authors have no conflicts of interest to declare.

Ethical Statement: The authors are accountable for all aspects of the work in ensuring that questions related to the accuracy or integrity of any part of the work are appropriately investigated and resolved.

Open Access Statement: This is an Open Access article distributed in accordance with the Creative Commons Attribution-NonCommercial-NoDerivs 4.0 International License (CC BY-NC-ND 4.0), which permits the noncommercial replication and distribution of the article with the strict proviso that no changes or edits are made and the original work is properly cited (including links to both the formal publication through the relevant DOI and the license). See: https://creativecommons.org/licenses/by-nc-nd/4.0/.

\section{References}

1. Vural KM, Sener E, Taşdemir O, et al. Approach to sinus of Valsalva aneurysms: A review of 53 cases. Eur J Cardiothorac Surg 2001;20:71-6.

2. Weinreich M, Yu PJ, Trost B. Sinus of Valsalva Aneurysms:
Review of the Literature and an Update on Management. Clin Cardiol 2015;38:185-9.

3. Omeh DJ, Makaryus AN. Unruptured Multiple Sinus of Valsalva Aneurysms. Case Rep Radiol 2020;2020:5046095.

4. Vijay BA, Vijan V, Mathew N. Surviving All Odds: A Unique Case of Multiple Congenital Unruptured Sinus of Valsalva Aneurysms Involving Both Left and Right Coronary Sinuses with Biventricular Dysfunction and Heart Block. Case Rep Cardiol 2016;2016:4654031.

5. Chigurupati K, Kumaresan B, Gadhinglajkar S, et al. Multiple unruptured aortic sinus of Valsalva aneurysms: A rare presentation. Echocardiography 2017;34:317-9.

6. Yan F, Abudureheman M, Huo Q, et al. Surgery for sinus of Valsalva aneurysm: 33-year of a single center experience. Chin Med J (Engl) 2014;127:4066-70.

7. Choudhary SK, Bhan A, Sharma R, et al. Sinus of Valsalva aneurysms: 20 years' experience. J Card Surg 1997;12:300-8.

8. Pólos M, Șulea CM, Benke K, et al. Giant unruptured sinus of Valsalva aneurysm successfully managed with valve-sparing procedure - a case report. J Cardiothorac Surg 2020;15:6.

9. Serban AM, Bătrâna N, Cocoi M, et al. The role of echocardiography in the diagnosis and management of a giant unruptured sinus of Valsalva aneurysm. Med Ultrason 2019;21:194-6.

10. Wang B, Ma D, Qu L, et al. Sinus of Valsalva aneurysm protruding into the mitral anterior leaflet causing dyspnea: A CARE-compliant case report. Medicine (Baltimore) 2019;98:e18169.

11. Umeda H, Isotani A, Arita T, et al. Rapid growth of thrombus formation in the unruptured sinus of Valsalva aneurysm following coronary angiography. J Echocardiogr 2018;16:182-4.

12. Qian H, Ouyang Q, Li Y, et al. Compression of left ventricle by a rare giant unruptured sinus of Valsalva aneurysm. Anatol J Cardiol 2016;16:E1-2.

13. Khanna R, Shah P, Dey M, et al. Unruptured sinus of Valsalva aneurysm mimicking as right atrial tumor. Echocardiography 2017;34:1107-9.

14. Ponti A, Qanadli SD, Kirsch M, et al. Left sinus of Valsalva aneurysm as a cause of chronic stable angina. Interact Cardiovasc Thorac Surg 2017;24:967-8.

15. Luo Y, Fang Z, Meng W. A giant aneurysm of noncoronary sinus of Valsalva concomitant with aortic regurgitation and mitral regurgitation. Echocardiography 2017;34:796-8.

16. Guner A, Celik M, Kahyaoglu M, et al. Multiple aneurysmatic involvement of sinus of Valsalva. Echocardiography 2017;34:627-8. 
17. Giambruno V, Cucchietti C, Pisano C, et al. Alternative Surgical Approach to Repairing a Giant Sinus of Valsalva Aneurysm. Tex Heart Inst J 2016;43:43-4.

18. Prifti E, Ademaj F, Baboci A, et al. Surgical treatment of a giant unruptured aneurysm of the noncoronary sinus of Valsalva: a case report. J Med Case Rep 2016;10:252.

19. Sato Y, Kawasaki T, Yamano M, et al. Unusual clinical course after surgical repair of unruptured aneurysm of sinus of Valsalva. J Med Ultrason (2001) 2016;43:523-6.

20. Karvounaris S, Michas G, Karampetsos V, et al. Giant Unruptured Left Sinus of Valsalva Aneurysm as an Unusual Cause of Ischemic Heart Failure. Hellenic J Cardiol 2015;56:441-3.

21. Gong W, Ye X, Wang Z, et al. Two balls around aortic root: Multiple huge unruptured aneurysms of the Valsalva sinus. Eur Heart J Cardiovasc Imaging 2015;16:827.

22. Chikkabasavaiah NA, Patra S, Basavappa R, et al. Large unruptured sinus of valsalva aneurysm dissecting into interventricular septum and presenting as a complex myocardial cystic mass. Echocardiography 2014;31:E207-11.

23. Ogiwara M, Ozaki M, Iwazaki M, et al. Multiple recurrent sinus of valsalva aneurysms. J Card Surg 2013;28:677-9.

24. Schönrath F, Alkadhi H, Landmesser U, et al. Giant unruptured sinus valsalva aneurysm: An unusual cause of typical angina. Eur Heart J 2013;34:1608.

25. Minagawa T, Watanabe S, Kanda K, et al. Surgical treatment for an asymptomatic and unruptured sinus of Valsalva aneurysm: Report of a case. Surg Today 2013;43:1199-201.

26. Lu S, Sun X, Wang C, et al. Surgical correction of giant extracardiac unruptured aneurysm of the right coronary sinus of Valsalva: Case report and review of the literature. Gen Thorac Cardiovasc Surg 2013;61:143-6.

27. Hu Y, Chen J, Zhong Q. Modified repair for huge unruptured aneurysm of the right sinus of valsalva. Thorac Cardiovasc Surg 2013;61:323-6.

28. Jouni H, Driver SL, Wright RS, et al. Danger above: a classic case of an unruptured right sinus of Valsalva aneurysm. BMJ Case Rep 2012;2012:bcr2012007437.

29. Yagoub H, Srinivas BP, McCarthy J, et al. Gigantic unruptured sinus of Valsalva aneurysm presenting as an incidental murmur. BMJ Case Rep 2012;2012:bcr2012006824.

30. Saritas A, Unal EU, Caliskan A, et al. Unruptured sinus of valsalva aneurysm displacing the right atrium. Eur J Cardiothorac Surg 2012;42:745.

31. Xu B, Kocyigit D, Betancor J, et al. Sinus of Valsalva
Aneurysms: A State-of-the-Art Imaging Review. J Am Soc Echocardiogr 2020;33:295-312.

32. Altarabsheh SEI, Araoz PA, Deo SV, et al. Unruptured sinus of valsalva aneurysm involving all three sinuses. Ann Thorac Surg 2011;91:e26-7.

33. Gupta M, Haseen MA, Shrivastav A, et al. Giant Unruptured Calcified Aneurysm of Non-coronary Sinus of Valsalva. Heart Lung Circ 2010;19:629.

34. Sohal M, Rajani R, De Belder A. Sinus of Valsalva aneurysm - An unusual cause of syncope. Echocardiography 2010;27:E60-1.

35. Rosu C, Basile F, Prieto I, et al. Unusual presentation of an isolated unruptured aneurysm of the right sinus of Valsalva causing compression of the right ventricular outflow tract. Eur J Cardiothorac Surg 2010;38:504.

36. Gunay R, Sensoz Y, Kayacioglu I. Giant unruptured noncoronary sinus of Valsalva aneurysm presenting as tricuspid stenosis. Eur J Cardiothorac Surg 2010;37:1471.

37. Tang G, Liu Y. 64-Row MDCT demonstration of an unruptured aneurysm of the sinus of Valsalva. J Card Surg 2010;25:70-1.

38. Bhat PS, Babu M, Gehlot R, et al. Aneurysm of all 3 sinuses of Valsalva causing coronary insufficiency. Asian Cardiovasc Thorac Ann 2009;17:637-9.

39. Matteucci MLS, Rescigno G, Capestro F, et al. Syncope triggered by a giant unruptured sinus of Valsalva aneurysm. Interact Cardiovasc Thorac Surg 2009;9:1047-8.

40. Michiels V, Salgado R, Vrints C, et al. Sinus of Valsalva Aneurysm. J Am Coll Cardiol 2009;54:876.

41. Ravindranath KS, Bhat S, Subramanyam KS, et al. Rare presentation of unruptured sinus of valsalva aneurysm involving all three sinuses. Indian Heart J 2009;61:121-2.

42. Darabian S, Ahmadi SH, Abbasi K, et al. Giant unruptured noncoronary sinus of valsalva aneurysm. J Card Surg 2009;24:351-3.

43. Sasaki S, Asano M, Fukuda K, et al. Unruptured Sinus of Valsalva Aneurysm Suspected to Be a Cardiac Tumor. Ann Thorac Surg 2009;87:1619.

44. Yang Y, Zhou Y, Ma L, et al. Unruptured aneurysm of the sinus of valsalva presenting with thrombosis and right ventricular outflow obstruction. J Card Surg 2008;23:782-4.

45. Fukui S, Mitsuno M, Yamamura M, et al. Successful Repair of Unruptured Aneurysm of the Right Sinus of Valsalva. Ann Thorac Surg 2008;86:640-3.

46. Klein LW, Chavez JR, Montoya A. Giant Unruptured Sinus of Valsalva Aneurysm. J Invasive Cardiol 2008;20:258.

47. Zannis K, Tzvetkov B, Deux JF, et al. Unruptured 
congenital aneurisms of the right and left sinuses of Valsalva. Eur Heart J 2007;28:1565.

48. Vermeulen T, Claeys M, Vrints C. Unruptured sinus of Valsalva aneurysm presenting as acute coronary syndrome. Acta Cardiol 2006;61:665-7.

49. Yilik L, Lafci B, Özsöyler I, et al. Giant extracardiac unruptured sinus of Valsalva aneurysm in a patient with left ventricular dysfunction. Heart Vessels 2006;21:328-30.

50. Joshi P, Garlick B, Dunning J. Modified Root Reconstruction Methods to Treat Unruptured Aneurysm of Sinus of Valsalva (UASOV) - Two Case Reports. Heart Lung Circ 2006;15:389-92.

51. Shin JK, Jung JP, Park CR, et al. Acute myocardial infarction due to unruptured aneurysm of left sinus of valsalva with aortic valve regurgitation. J Card Surg 2005;20:545-8.

52. Mookadam F, Haley J, Mendrick E. Rare cause of right heart failure: Contained rupture of a sinus of Valsalva aneurysm associated intraventricular septal aneurysm. Eur J Echocardiogr 2005;6:221-4.

53. Akashi H, Tayama E, Tayama K, et al. Remodeling operation for unruptured aneurysms of three sinuses of

Cite this article as: Nguyen Q, Vervoort D, Phan K, Luc JGY. Surgical management for unruptured sinus of Valsalva aneurysms: a narrative review of the literature. J Thorac Dis 2021;13(3):1833-1850. doi: 10.21037/jtd-20-2682
Valsalva. J Thorac Cardiovasc Surg 2005;129:951-2.

54. Sharda A, Yadava OP, Dubey S, et al. Unruptured sinus of Valsalva aneurysm presenting as acute coronary syndrome. Indian Heart J 2004;56:155-7.

55. Mohanakrishnan L, Vijayakumar K, Sukumaran P, et al. Unruptured sinus of valsalva aneurysm with right ventricular outflow obstruction. Asian Cardiovasc Thorac Ann 2003;11:74-6.

56. Banerjee S, Jagasia DH. Unruptured sinus of Valsalva aneurysm in an asymptomatic patient. J Am Soc Echocardiogr 2002;15:668-70.

57. Lijoi A, Parodi E, Passerone GC, et al. Unruptured aneurysm of the left sinus of Valsalva causing coronary insufficiency: Case report and review of the literature. Tex Heart Inst J 2002;29:40-4.

58. Rhew JY, Jeong MH, Kang KT, et al. Huge calcified aneurysm of the sinus of Valsalva. Jpn Circ J 2001;65:239-41.

59. Tsukui H, Hoshino S, Saito N, et al. Giant extracardiac unruptured aneurysm of the sinus of Valsalva: A case report. Heart Vessels 2000;15:289-90. 